\title{
An improved bathymetry compilation for the Bellingshausen Sea, Antarctica, to inform ice-sheet and ocean models
}

\author{
A. G. C. Graham ${ }^{1}$, F. O. Nitsche ${ }^{2}$, and R. D. Larter ${ }^{1}$ \\ ${ }^{1}$ Ice Sheets programme, British Antarctic Survey, High Cross, Madingley Road, Cambridge, CB3 0ET, UK \\ ${ }^{2}$ Lamont Doherty Earth Observatory of Columbia University, 61 Route 9W, Palisades, New York, 10964, USA
}

Received: 30 September 2010 - Published in The Cryosphere Discuss.: 15 October 2010

Revised: 14 January 2011 - Accepted: 3 February 2011 - Published: 16 February 2011

\begin{abstract}
The southern Bellingshausen Sea (SBS) is a rapidly-changing part of West Antarctica, where oceanic and atmospheric warming has led to the recent basal melting and break-up of the Wilkins ice shelf, the dynamic thinning of fringing glaciers, and sea-ice reduction. Accurate sea-floor morphology is vital for understanding the continued effects of each process upon changes within Antarctica's ice sheets. Here we present a new bathymetric grid for the SBS compiled from shipborne multibeam echo-sounder, spot-sounding and sub-ice measurements. The $1-\mathrm{km}$ grid is the most detailed compilation for the SBS to-date, revealing large cross-shelf troughs, shallow banks, and deep innershelf basins that continue inland of coastal ice shelves. The troughs now serve as pathways which allow warm deep water to access the ice sheet in the SBS. Our dataset highlights areas still lacking bathymetric constraint, as well as regions for further investigation, including the likely routes of palaeoice streams. The new compilation is a major improvement upon previous grids and will be a key dataset for incorporating into simulations of ocean circulation, ice-sheet change and history. It will also serve forecasts of ice stability and future sea-level contributions from ice loss in West Antarctica, required for the next IPCC assessment report in 2013.
\end{abstract}

\section{Introduction}

Contributions to sea level from 21st Century changes in the West Antarctic ice sheet (WAIS) will form a key part of the Fifth Assessment Report of the IPCC due in 2013. Glaciologists, oceanographers, modellers and geologists are currently working in tandem to better constrain the modern-day thin-

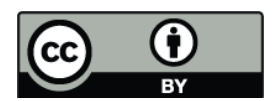

Correspondence to: A. G. C. Graham (alah@bas.ac.uk) ning and acceleration of the WAIS, measure changes to its glaciers and ice shelves at ocean margins, and estimate the impacts of future changes on the environment (including sea level), with implications for society as a whole (e.g. Overpeck and Weiss, 2009).

A concerted focus of West Antarctic studies is on the southern Bellingshausen Sea (SBS), fed by ice draining the WAIS as well as the adjoining Antarctic Pensinusla Ice Sheet, where major changes are already taking place (Fig. 1a). In May 2008 the Wilkins ice shelf dramatically disintegrated and recent satellite measurements of icesurface elevation have indicated that glaciers which drain into the SBS have undergone dynamic thinning (thinning as a result of flow acceleration) related to warming delivered through the oceans (Rignot and Jacobs, 2002; Pritchard et al., 2009), and as a result of the southerly migration of regional isotherms (i.e. atmospheric warming; Cook and Vaughan, 2010). A major ice stream, Ferrigno Glacier, which drains into Eltanin Bay, thinned by more than $0.5 \mathrm{~m} \mathrm{yr}^{-1}$ between 2003-2007 (Pritchard et al., 2009) and currently exhibits thinning rates of ca. $-6 \mathrm{~m} \mathrm{yr}^{-1}$ at its grounding line. Oceanographic data have also shown the SBS is a key area where warm Circumpolar Deep-Water (CDW; temperature $\geq 1.0^{\circ} \mathrm{C}$, salinity $34.7 \mathrm{psu}$ ) periodically floods onto the shelf (Talbot, 1988; Jenkins and Jacobs, 2008), and coupled thermodynamic models indicate that ice shelves in the SBS have been thinning rapidly as a result of basal melting, possibly for some decades (Holland et al., 2010). Reduction in sea ice since the 1970s is another indicator that the SBS is undergoing considerable environmental stress (Jacobs and Comiso, 1997). Thus it is of little surprise that a major focus of UK and US environmental research is the fast-changing SBS area.

Topography is a key input parameter for any ice or ocean model addressing issues of change since the existence of troughs and other landforms controls the delivery of oceanic

Published by Copernicus Publications on behalf of the European Geosciences Union. 
a

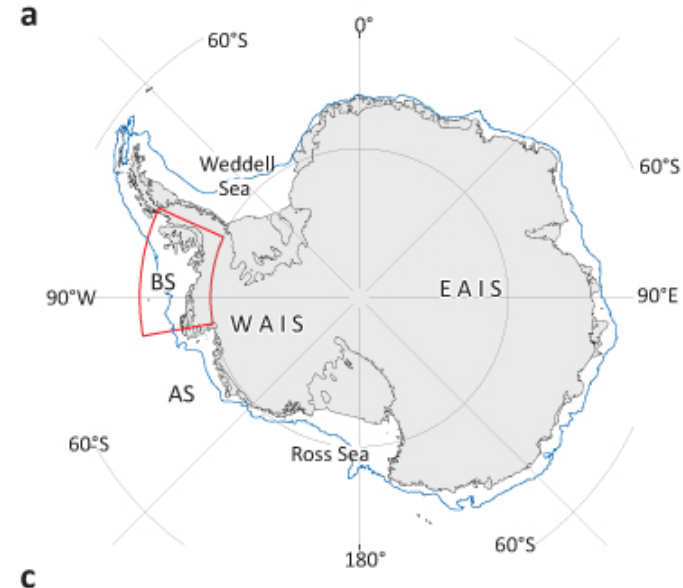

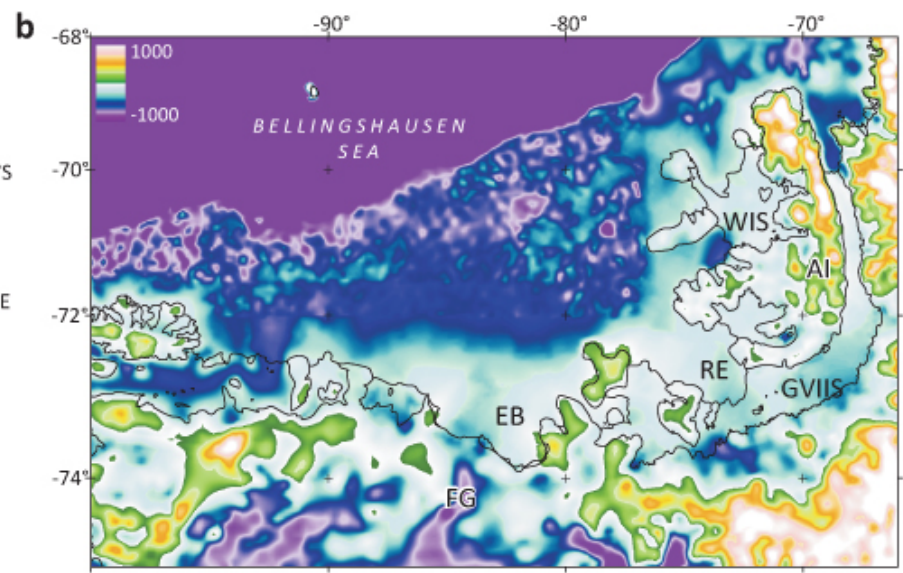

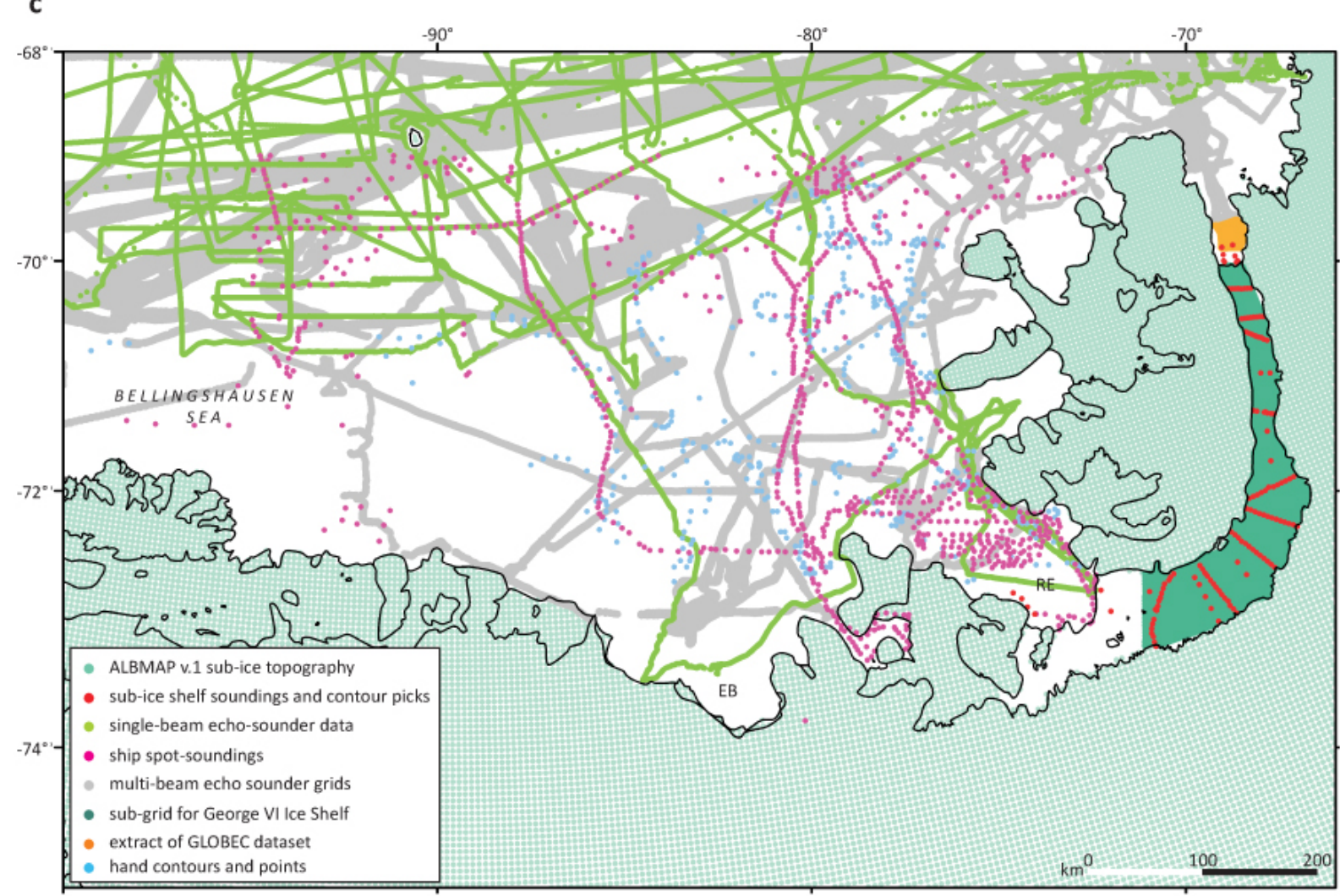

Fig. 1. (a) Location map showing the Antarctic ice sheets, the continental shelf edge (blue) and area covered by the new bathymetry grid (red); South Pole Stereographic projection. (b) Existing bathymetry in the Bellingshausen Sea rendered from ALBMAP v.1.1. (Le Brocq et al., 2010). WGS84 Mercator projection. EB: Eltanin Bay; FG: Ferrigno Glacier; RE: Ronne Entrance; WIS: Wilkins Ice Shelf; AI: Alexander Island; GVIIS: George VI Ice Shelf (c) data types and their distribution for the new bathymetric compilation; coastline drawn from the ADD v.4.1. Table 1 provides additional details. WGS84 Mercator projection.

heat to the ice sheet (e.g., Thoma et al., 2008). In addition, without realistic boundary conditions, models will not simulate the evolution of the ice sheets accurately and may misrepresent future contributions to climate change or sea level as a result. In the SBS, the current landscape beneath the ice is underexplored and poorly known despite an ever-increasing ability to quantify subglacial topography (e.g. Pritchard and Bingham, 2007). For example, during a recent radar survey of the Ferrigno Glacier, Bingham et al. (2010; unpublished data) discovered a $>3000$ metre-deep sub-ice trough, that is not represented in any existing topography (e.g. BEDMAP; Lythe et al., 2001). Likewise, the bathymetry of the SBS is often poorly represented in grids that are frequently used by modellers to simulate ice changes 
and ocean circulation. A recent compilation of Antarctica's bed by Le Brocq et al. (2010) highlighted the weakness of bathymetry in regional compilations of Antarctic topography (Fig. 1b). While some regions are now well represented (e.g. the Amundsen Sea; Nitsche et al., 2007), the gridded bathymetry from the SBS remains inadequate for showing how the ice and ocean interact there. An improved topography for the sea floor was recently presented by Timmerman et al. (2010), but the grid was based on only a handful of the available sounding datasets for the embayment and failed to resolve some of the key topographic features clearly including the outline of the shelf break. Better bathymetry is needed urgently for this region, given that models of changes in the cryosphere (including the ice-sheet and ocean) will directly inform the next IPCC assessments of climate change and sea-level rise.

In this paper, a new bathymetric grid is presented for the continental shelf and slope for the region $100-66^{\circ} \mathrm{W}, 75-$ $68^{\circ} \mathrm{S}$ in the Bellingshausen Sea (Fig. 1a). Existing grids for the area show a variety of different topographies but none clearly define the detailed morphology of the shelf, including the shelf edge and major cross-shelf troughs that have been partially imaged on multibeam echo-sounder data in the area (e.g. Ó Cofaigh et al., 2005b; Dowdeswell et al., 2008; Noormets et al., 2009).

\section{Approach and method}

Syntheses of depth soundings into representations of seafloor topography have traditionally been carried out by hydrographers who draw contour maps by hand to portray inferred morphology (Sandwell et al., 2001). However, these methods are imprecise and often non-reproducible. An alternative and successful method for producing bathymetry in deep ocean areas is to apply an inversion to satellite gravity data, but there are severe limitations to recovering sea-floor topography from radar altimetry: namely, its moderate resolution and problems of noise in gravity anomaly measurements of the ocean surface slope (Smith and Sandwell, 1994; Macnab, 2009). This is particularly the case along polar continental margins, as in the SBS, where sea-ice cover and variations in thickness of the crust and sedimentary strata are significant factors affecting the gravity anomaly field. Furthermore bathymetry data generated from inversion of Geosat data do not extend beyond $72^{\circ} \mathrm{S}$. Therefore, for the purpose of regional ice or ocean modelling on a continental shelf we consider the best bathymetric representation to be derived principally from in situ shipborne measurements.

We followed a procedure established by other workers to produce a bathymetric compilation for the Bellingshausen Sea. Our approach mirrors closely that of Nitsche et al. (2007), Fretwell et al. (2009) and Beaman et al. (2011), aggregating ship soundings from many expeditions and com- bining them with other spatial data (sub-ice, sub-ice-shelf and land) to produce a continuous regional chart (Fig. 1c).

As primary context, sub-ice "bed" elevation data were extracted from ALBMAP v.1 (LeBrocq et al., 2010) masked to the ice fronts and coastline drawn from the Antarctic Digital Database v.4.1. We converted the 5-km netcdf grid to xyz points and added these to our input dataset. Next, multibeam data were gridded at 300-m cell size using the mbgrid tool in MB-system (Caress and Chayes, 2006) with a Gaussian weighted averaging function and allowed a free interpolation to the limit of 2 grid cells $(0.6-\mathrm{km}$ radius; N.B. version 1.1 . of the grid). The grid included new swath bathymetry tracks collected by the RRS James Clark Ross in 2008 and RV Oden in 2009/2010. The majority of multibeam datasets had already been ping-edited to ensure removal of spurious data prior to our obtaining them for inclusion in the compilation. Single beam echo-sounding data were compiled from a number of additional cruises of the James Clark Ross, RV Nathanial B. Palmer, RV Eltanin, RV Polar Duke, and RV Polarstern (Table 1) and included in the grid. Ship-based spot soundings from the Bellingshausen Sea UK Hydrographic Office Collector's Sheet were also digitised and added to the dataset (Fig. 1c). These single soundings are particularly significant in areas where multibeam coverage is lacking and soundings from other scientific cruises are sparse.

To the west of the study area there are few data points to constrain topography and here we steered the grid towards a shelf edge shape that is consistent with the satellitederived gravity anomaly field by adding a $-580 \mathrm{~m}$ contour approximating the shelf-edge from the Smith and Sandwell gravity-derived topographic grid (Smith and Sandwell, 1997; Fig. 1c). However our use of these data was minimal, amounting to ca. $<0.001 \%$ of the total dataset (11 points from a total of $\sim 1400000$ ). In addition, we digitised sub-ice shelf topography from Maslanyj's (1987) seismic soundings of the George VI Ice Shelf (GVIIS) and removed inaccurate shallow soundings from the ALBMAP point-set (inherited from BEDMAP) using a mask tool. To avoid aliasing issues due to its narrow rift walls, we gridded the bathymetry of GVIIS separately to the remainder of the grid with a minimum curvature spline at $1-\mathrm{km}$ grid spacing. The resulting raster was integrated into the compilation before final gridding.

A by-product of including this separate dataset was the occurrence of a prominent ridge at the northern front of GVIIS, which resulted from the interpolation between deep sub-ice shelf bathymetry and shallow parts of the GLOBEC dataset on the inner shelf (Bolmer, 2008). No evidence for this ridge was found in existing bathymetric soundings indicating that anomalously shallow grid values in the GLOBEC grid were artificially "pulling up" bathymetry at the ice front. As a potential obstacle to motion of the grounding-line and ocean throughflow, the ridge was identified as an artefact and removed from the compilation by adding six control points at the northern ice front to constrain bathymetry to a sensible 
Table 1. Data sets used in the new bathymetry compilation. SBES: single-beam echo sounder data; MBES: multibeam echo-sounder data; PI (Principal Investigator).

\begin{tabular}{|c|c|c|c|c|c|}
\hline \multicolumn{2}{|r|}{ Data set } & \multirow[b]{2}{*}{ Year } & \multicolumn{2}{|c|}{ Accuracy estimate } & \multirow[b]{2}{*}{ Reference $^{\mathrm{f}}$} \\
\hline Type & Cruise/ID & & Vert. & Horiz. & \\
\hline \multirow{3}{*}{$\begin{array}{l}\text { Sub-ice } \\
\text { topography }\end{array}$} & ALBMAP v.1 (5 km grid) & 2010 & N/A & N/A & Le Brocq et al. (2010) \\
\hline & Maslanyj GVIIS soundings & 1987 & N/A & N/A & Maslanyj (1987) \\
\hline & $\begin{array}{l}\text { Maslanyj contours, digitised } \\
\text { (selected points) }\end{array}$ & 1987 & N/A & N/A & Maslanyj (1987) \\
\hline \multirow[t]{22}{*}{ MBES } & JR59 & 2001 & $1-8 \mathrm{~m}^{\mathrm{a}}$ & $5 \mathrm{~m}^{\mathrm{a}}$ & Ó Cofaigh et al. (2002) \\
\hline & JR71 & 2002 & $1-8 \mathrm{~m}^{\mathrm{a}}$ & $5 \mathrm{~m}^{\mathrm{a}}$ & Ó Cofaigh et al. (2005b) \\
\hline & JR84 & 2003 & $1-8 \mathrm{~m}^{\mathrm{a}}$ & $5 \mathrm{~m}^{\mathrm{a}}$ & A. Jenkins (PI) \\
\hline & JR104 & 2004 & $1-8 \mathrm{~m}^{\mathrm{a}}$ & $5 \mathrm{~m}^{\mathrm{a}}$ & Ó Cofaigh et al. (2005a) \\
\hline & JR141 & 2006 & $1-8 \mathrm{~m}^{\mathrm{a}}$ & $5 \mathrm{~m}^{\mathrm{a}}$ & Larter et al. (2007) \\
\hline & JR157 & 2007 & $1-8 \mathrm{~m}^{\mathrm{a}}$ & $5 \mathrm{~m}^{\mathrm{a}}$ & Noormerts et al. (2009) \\
\hline & JR165 & 2007 & $1-8 \mathrm{~m}^{\mathrm{a}}$ & $5 \mathrm{~m}^{\mathrm{a}}$ & D. Shoosmith (PI) \\
\hline & JR179 & 2008 & $1-8 \mathrm{~m}^{\mathrm{a}}$ & $5 \mathrm{~m}^{\mathrm{a}}$ & Graham et al. (2010) \\
\hline & NBP9902 & 1999 & $1-8 \mathrm{~m}^{\mathrm{a}}$ & $5 \mathrm{~m}^{\mathrm{a}}$ & Wellner et al. (2001) \\
\hline & NBP0001 & 2000 & $1-8 \mathrm{~m}^{\mathrm{a}}$ & $5 \mathrm{~m}^{\mathrm{a}}$ & Anderson et al. (2002) \\
\hline & NBP0103 & 2001 & $1-8 \mathrm{~m}^{\mathrm{a}}$ & $5 \mathrm{~m}^{\mathrm{a}}$ & P. Wiebe (PI) \\
\hline & NBP0104 & 2001 & $1-8 \mathrm{~m}^{\mathrm{a}}$ & $5 \mathrm{~m}^{\mathrm{a}}$ & P. Wiebe (PI) \\
\hline & NBP0105 & 2001 & $1-8 \mathrm{~m}^{\mathrm{a}}$ & $5 \mathrm{~m}^{\mathrm{a}}$ & R. Smith (PI) \\
\hline & NBP0202 & 2002 & $1-8 \mathrm{~m}^{\mathrm{a}}$ & $5 \mathrm{~m}^{\mathrm{a}}$ & P. Wiebe (PI) \\
\hline & NBP0204 & 2002 & $1-8 \mathrm{~m}^{\mathrm{a}}$ & $5 \mathrm{~m}^{\mathrm{a}}$ & P. Wiebe (PI) \\
\hline & NBP0702 & 2007 & $1-8 \mathrm{~m}^{\mathrm{a}}$ & $5 \mathrm{~m}^{\mathrm{a}}$ & S. Jacobs (PI) \\
\hline & NBP0709 (500 m grid) & 2007 & $1-8 \mathrm{~m}^{\mathrm{a}}$ & $5 \mathrm{~m}^{\mathrm{a}}$ & S. Ackley (PI) \\
\hline & ANT11/3 & 1994 & $1.2-8.5 \mathrm{~m}^{\mathrm{b}}$ & $<10 \mathrm{~m}^{\mathrm{c}}$ & Miller and Grobe (1994) \\
\hline & ANT23/4 & 2006 & $1.2-8.5 \mathrm{~m}^{\mathrm{b}}$ & $<10 \mathrm{~m}^{\mathrm{c}}$ & Gohl (2006) \\
\hline & NOAA RITS94B (150 m grid) & 1994 & $1.2-8.5 \mathrm{~m}^{\mathrm{b}}$ & $<10 \mathrm{~m}^{\mathrm{c}}$ & T. Bates (PI) \\
\hline & EW9101 & 1991 & $1.2-8.5 \mathrm{~m}^{\mathrm{b}}$ & $<10 \mathrm{~m}^{\mathrm{c}}$ & J. Austin (PI) \\
\hline & Oden OS0910 (500 m grid $)$ & 2010 & $1-<8 \mathrm{~m}^{\mathrm{d}}$ & $<10 \mathrm{~m}^{\mathrm{c}}$ & J. Anderson/F. Nitsche (PI) \\
\hline \multirow[t]{12}{*}{ SBES } & JR04 & 1993 & $<4-40 \mathrm{~m}^{\mathrm{e}}$ & $<10 \mathrm{~m}^{\mathrm{c}}$ & P. Barker (PI) \\
\hline & NBP9208 & 1992 & $<4-40 \mathrm{~m}^{\mathrm{e}}$ & $<10 \mathrm{~m}^{\mathrm{c}}$ & C. Raymond (PI) \\
\hline & ANT11/3 (centrebeam) & 1994 & $<4-40 \mathrm{~m}^{\mathrm{e}}$ & $<10 \mathrm{~m}^{\mathrm{c}}$ & Miller and Grobe (1994) \\
\hline & ANT12/4 (centrebeam) & 1995 & $<4-40 \mathrm{~m}^{\mathrm{e}}$ & $<10 \mathrm{~m}^{\mathrm{c}}$ & R. Gersonde (PI) \\
\hline & ANT18/5 (centrebeam) & 2001 & $<4-40 \mathrm{~m}^{\mathrm{e}}$ & $<10 \mathrm{~m}^{\mathrm{c}}$ & Bathmann (2002) \\
\hline & DSDP35 (centrebeam) & 1974 & $<4-40 \mathrm{~m}^{\mathrm{e}}$ & $<10 \mathrm{~m}^{\mathrm{c}}$ & Hollister and Craddock (1974) \\
\hline & ELT11 & 1963 & $<4-40 \mathrm{~m}^{\mathrm{e}}$ & $<10 \mathrm{~m}^{\mathrm{c}}$ & P. Smith (PI) \\
\hline & ELT17 & 1965 & $<4-40 \mathrm{~m}^{\mathrm{e}}$ & $<10 \mathrm{~m}^{\mathrm{c}}$ & M. Dawson (PI) \\
\hline & ELT42 & 1970 & $<4-40 \mathrm{~m}^{\mathrm{e}}$ & $<10 \mathrm{~m}^{\mathrm{c}}$ & R. Houtz (PI) \\
\hline & PD90L1 & 1990 & $<4-40 \mathrm{~m}^{\mathrm{e}}$ & $<10 \mathrm{~m}^{\mathrm{c}}$ & R. Smith (PI) \\
\hline & THB80 & N/A & N/A & N/A & \\
\hline & DF85 & 1985 & N/A & N/A & Kellogg and Kellogg (1987) \\
\hline \multirow[t]{4}{*}{ Other } & Collector sheet soundings & Various & N/A & N/A & \\
\hline & $\begin{array}{l}500 \text { and } 600 \mathrm{~m} \text { hand contours } \\
\text { from singlebeam soundings }\end{array}$ & N/A & N/A & N/A & \\
\hline & $\begin{array}{l}\text { Amundsen Sea regional } \\
\text { bathymetry compilation }(3 \mathrm{~km} \text { grid })\end{array}$ & 2007 & N/A & N/A & Nitsche et al. (2007) \\
\hline & $\begin{array}{l}\text { GLOBEC bathymetry, } \\
\text { northern front of GVIIS }\end{array}$ & 2008 & N/A & N/A & Bolmer (2008) \\
\hline
\end{tabular}

\footnotetext{
a Vertical and horizontal accuracy based on RMS accuracy of sonar systems, and after estimates in Dowdeswell et al. (2010).

b Other MBES system accuracy generally equal to $0.5 \mathrm{~m} \pm 0.2 \%$ of the water depth.

${ }^{\mathrm{c}}$ Estimated value but highly variable, dependent on acquisition parameters for individual surveys

d EM122 accuracy of $0.2 \%$ of the water depth.

e Based on sounding vertical accuracy better than $1 \%$ of water depth, but likely to be variable between and within surveys

${ }^{\mathrm{f}}$ Where available, otherwise cruise PI is listed.
} 


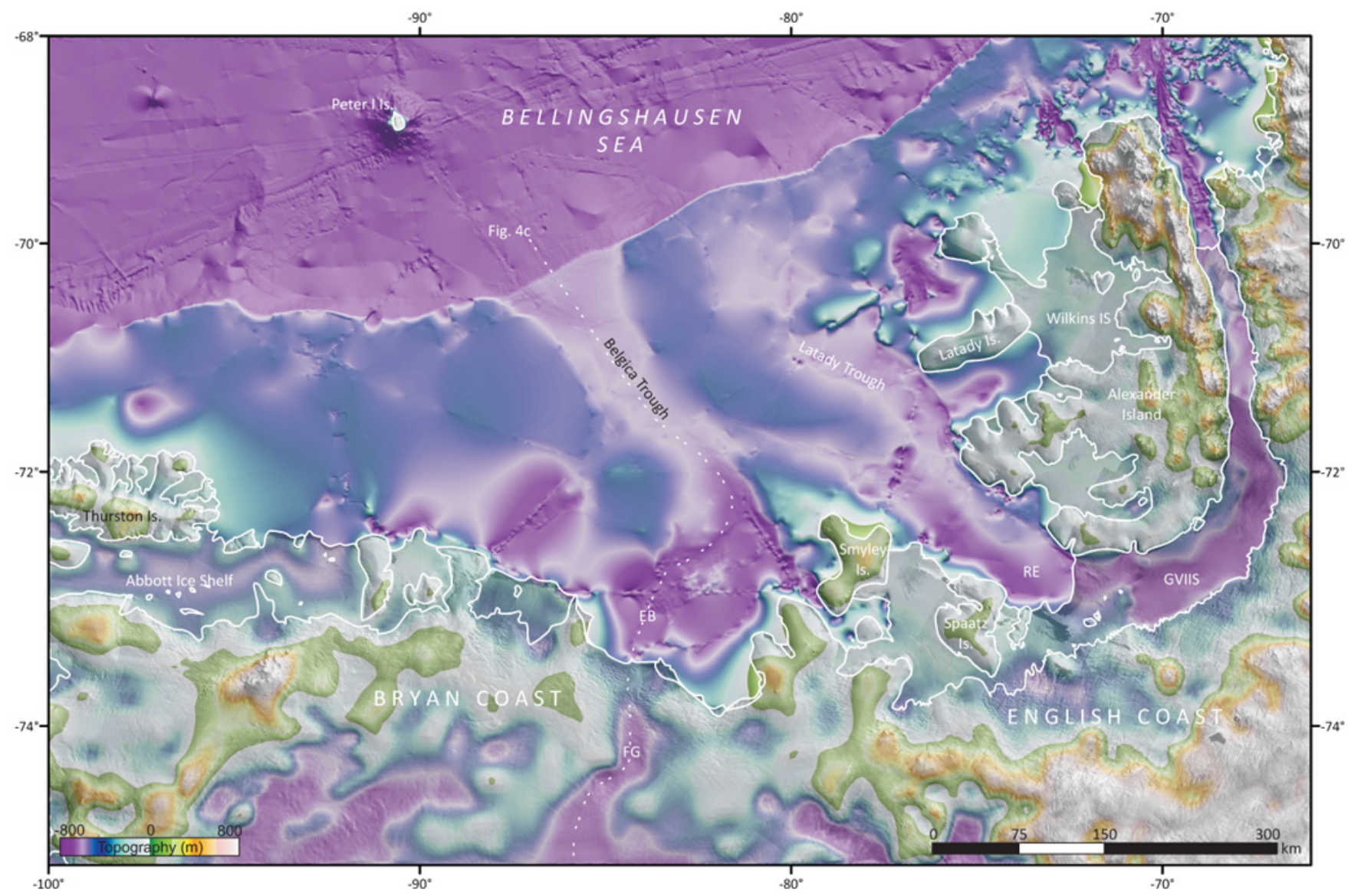

Fig. 2. Bathymetry of the Bellingshausen Sea. Grid cell size $1000 \mathrm{~m}$. Coastline drawn from the ADD v.4.1. and areas of the ice sheet are draped by a semi-transparent version of the LIMA raster image. Grid is compiled in South Pole stereographic projection, but shown here in Mercator WGS84 projection. The map is rendered here to accentuate shelf and sub-ice features, but a map highlighting deep-ocean features is shown in Fig. 3. Large format plot of the grid is available as Supplement Fig. S1.

and more realistic trough profile (Fig. 1c; see Discussions Paper and Supplement for further detail).

Lastly, we constrained the western edge of the grid by including a portion of the dataset presented in Nitsche et al. (2007). This method allows for near-seamless integration with their Amundsen Sea bathymetric grid.

Final gridding of a merged point file was carried out using the Natural Neighbour algorithm in ArcGIS 9.3 (Sibson, 1981). The interpolation tool finds the closest subset of input samples to an interpolation point and applies weights to them based on proportionate areas to interpolate a value. As data quality varies between the input surveys, several iterations were required to identify and remove anomalous measurements (e.g. data spikes from poorly-processed echo sounder data). We produced a continuous topography with a grid cell size of $1000 \mathrm{~m}$.

\section{Results}

The resulting grid is shown in Figs. 2 and 3. It covers an area of the shelf, slope, and ice-sheet interior $>810000 \mathrm{~km}^{2}$ in size. The continental shelf edge is well defined for the first time by the $-600 \mathrm{~m}$ contour, except at the mouth of the prominent Belgica Trough where the shelf break lies a little deeper at ca. $-700 \mathrm{~m}$ (cf. Timmerman et al., 2010). A few small re-entrants to the west of the grid are artefacts resulting from sparse input data, due to persistent ice cover north and northeast of Thurston Island which repeatedly prevents ship access (Figs. 1c, 2). Measured linearly from the coastline, the width of the shelf varies from very narrow $(\sim 100 \mathrm{~km})$ north of Charcot Island to broad $(400-480 \mathrm{~km})$ in the central Bellingshausen Sea (Fig. 2). Water depths on the shelf also vary considerably from $>1000 \mathrm{~m}$ in the deepest inner-shelf basins to ca. $400-500 \mathrm{~m}$ on shallower banks.

The main shelf feature is Belgica Trough, a $430-550 \mathrm{~km}$ long (measured on a curvilinear course through Eltanin Bay and Ronne Entrance, respectively), 50-120 km wide, and 


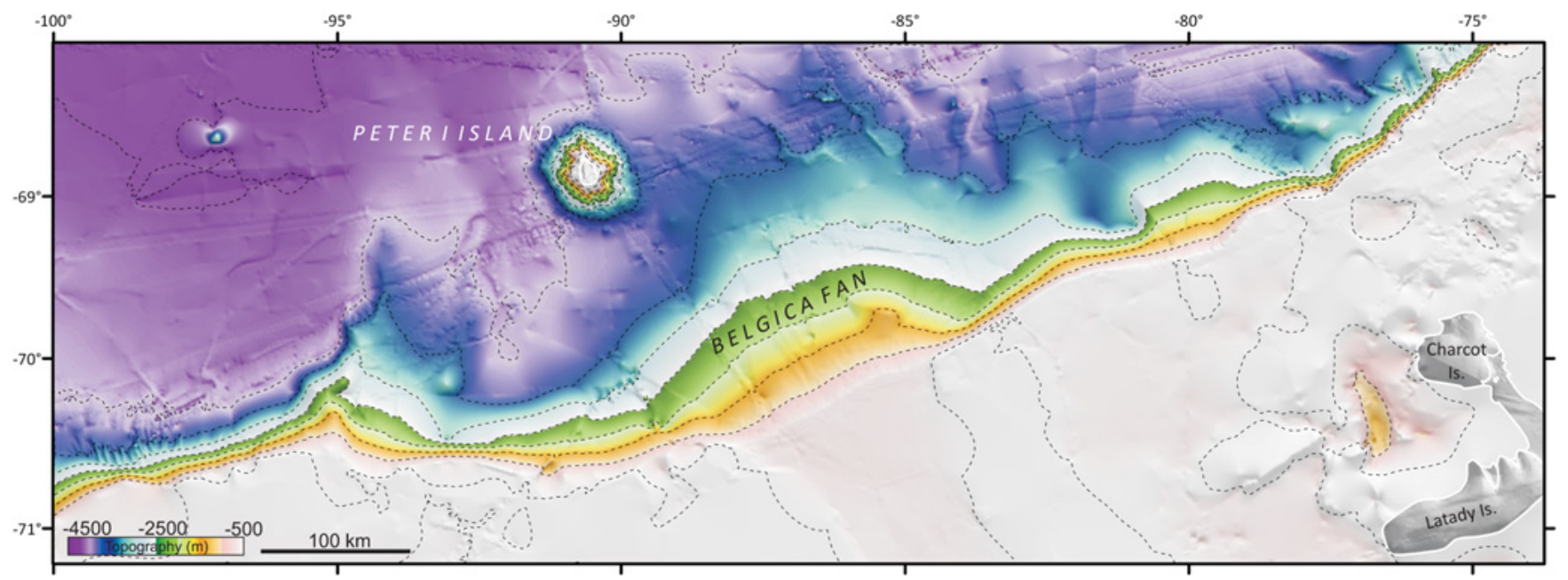

Fig. 3. New bathymetry for the Bellingshausen Sea continental margin, shaded to accentuate features on the continental slope and rise. Mercator projection. Contours are rendered at $500 \mathrm{~m}$ intervals.

200-600 m deep (from shoulder to thalweg) relict glacial trough that has been carved out and subsequently occupied by fast-flowing ice streams since at least the Pliocene (Figs. 2, 4; Nitsche et al., 2000; Scheuer et al., 2006). On the inner shelf, Belgica Trough is shown to be a convergent system connected by smaller tributary troughs to each of the Ronne Entrance and Eltanin Bay basins. The trough shoals from the inner shelf basins towards the middle shelf, before flattening out and deepening once again towards the shelf break (Fig. 4c), where the trough mouth also widens (Fig. 4a). A small, second order trough, known to exist on the outer shelf within Belgica Trough (Hillenbrand et al., 2009) and resolvable in TOPAS profiles across the trough axis (Fig. S2), is well imaged in the new bathymetric chart measuring ca. $25 \mathrm{~km}$ wide, and $30-40 \mathrm{~m}$ deep (Fig. $4 \mathrm{a}$ and b). A new u-shaped trough is also revealed in the bathymetry to the east of Belgica Trough, which we refer to as Latady Trough. Latady Trough originates in Wilkins Sound and possesses an additional connection to the Ronne Entrance (Fig. 2). It is $390 \mathrm{~km}$ long, up to $80 \mathrm{~km}$ wide, has an arcuate planform expression, and like the neighbouring Belgica Trough, features characteristics which suggest it has been glacially-carved (e.g., u-shaped, retrograde slope). In addition, the data suggest the presence of two smaller troughs on the inner shelf in the western part of the study area, near $87^{\circ} \mathrm{W}$ and $91^{\circ} \mathrm{W}$, but the data coverage is currently too sparse to outline their shape or extent (Fig. 2). Shallow banks, typically $400-500 \mathrm{~m}$ deep, separate the troughs and also characterise regions of the inner shelf between deeper basins (Fig. 2).

At the mouth of the Belgica Trough, a major glacial depositional centre (Belgica Fan; Dowdeswell et al., 2008) is represented in the new bathymetry, in its entirety, for the first time (Figs. 3 and 4a). It is characterised by widely-spaced slope contours and a clear bulge in the margin profile which becomes progressively exaggerated with increasing depth. A smaller fan may also exist on the outer shelf at the mouth of Latady Trough (at ca. $82^{\circ} \mathrm{W}$; Fig. 3), as inferred previously by Scheuer et al. (2006) and Noormets et al. (2009), with a potential third fan farther east at ca. $80^{\circ} \mathrm{W}$ (Fig. 3). In addition, other parts of the lower slope and upper continental rise are generally well imaged across our study area, including the bathymetry surrounding Peter I island at $\sim 90^{\circ} \mathrm{W}, 69^{\circ} \mathrm{S}$ (Figs. 3 and 4a). Refined bathymetry in this area will be particularly useful for future modelling of deep water circulation (Holland et al., 2010).

Some uncertainties still remain in the bathymetric chart. Seams between detailed multibeam bathymetry and interpolated areas can cause artefacts manifested as sudden changes in seafloor roughness, but these are a necessary trade-off in exchange for a higher grid resolution and more detail. Trackline artefacts such as these are common to most bathymetric compilations (e.g. Nitsche et al., 2007; Jakobsson et al., 2008). In addition, in areas with few data points, it should be noted that the vertical accuracy of the dataset is significantly reduced because in these areas the grid relies on interpolation over large sectors unconstrained by real measurements (e.g. north of Thurston Island). Figure 1c highlights several areas of the sea floor that remain entirely devoid of real observations. Likewise, sub-ice shelf bathymetry is still poor in the SBS. However, our inclusion of seismic soundings beneath George VI ice shelf greatly improves the bathymetry beneath the southern limb of the ice shelf, and our removal of ridge artefacts at the ice front also improves representation of the connection between the northern limb and Marguerite Bay (Fig. 2; see Supplement). 

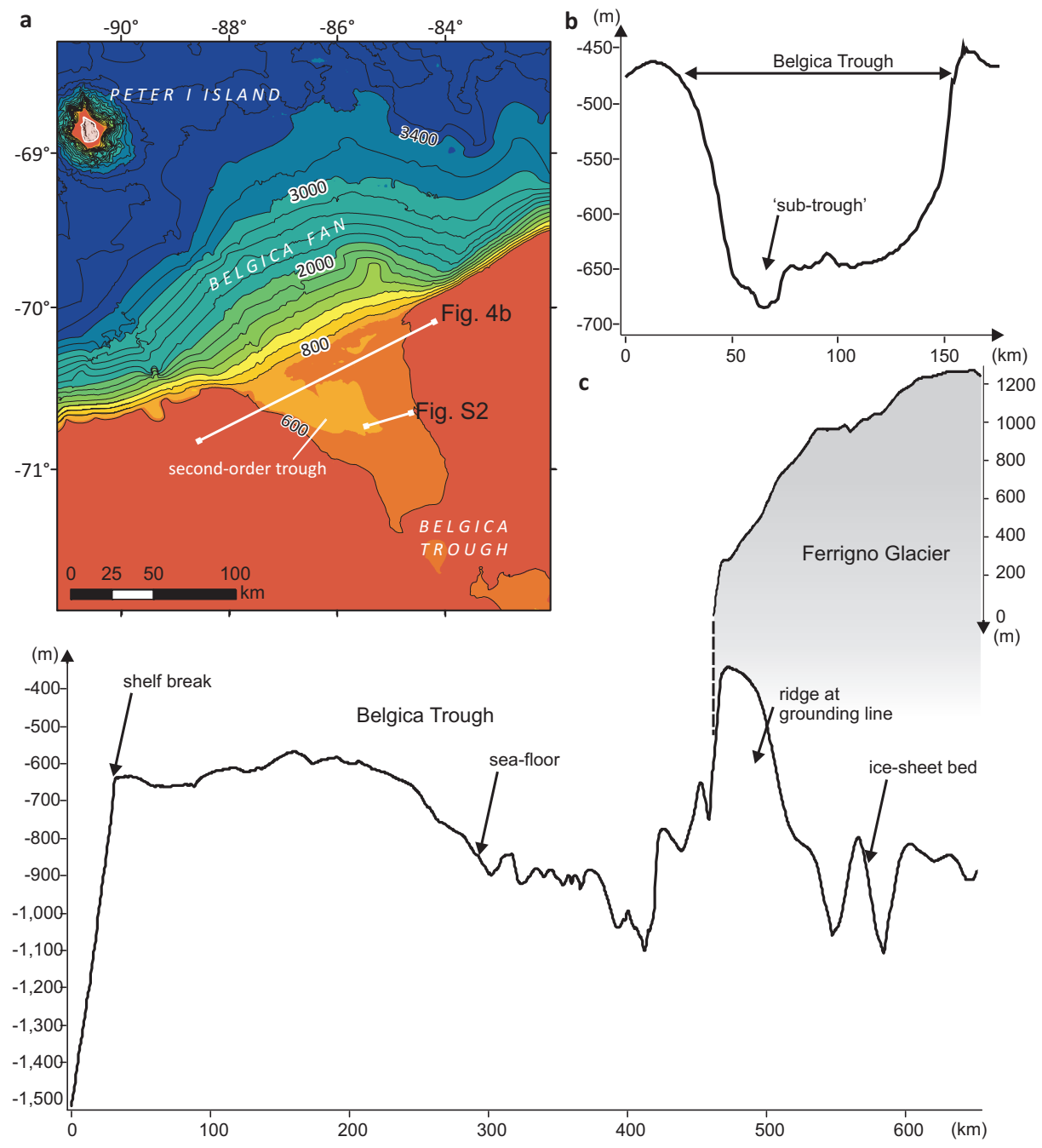

Fig. 4. (a) Bathymetry of the outer shelf near the mouth of Belgica Trough, showing the small second order sub-trough, the shelf edge, and the Belgica Fan; contours at $200 \mathrm{~m}$ intervals. (b) Cross-profile extracted from the new grid across the mouth of Belgica Trough; location shown in Fig. 4a. (c) Along-trough profile of the Belgica Trough and the Ferrigno Glacier basal topography, extracted from the new topographic grid. Note the unusual morphology of the outer shelf, and the apparent ridge at the glacier grounding line. Surface elevations of Ferrigno Glacier taken from the RadarSat DEM. For location, see Fig. 2.

Exact uncertainties are difficult to establish for the new grid, given the range of data types, vintages, and associated errors that make up the input dataset (e.g. some multibeam datasets with a vertical accuracy of e.g. 1-2 $\mathrm{m}$ versus older soundings with 10's of metres of potential error). Nevertheless, we provide some basic error estimates for the grid's input datasets in Table 1, based on the RMS accuracy of the shipboard sonar systems used during acquisition, for water depths relevant to this study. We acknowledge that other factors including sea-state, beam angle, sea-floor geology, sound velocity correction, and signal-to-noise ratio may drastically affect sonar accuracy. Thus we suggest that readers consult original data sources and related publications for further details of uncertainty associated with individual surveys (Table 1).
As well as errors in the data, uncertainties also exist in the grid interpolation process itself. To provide an estimate of gridding uncertainty, we took a sub-sample of 100000 input data points and compared their true (measured) elevation against the corresponding Z-value for the grid cell at that location. We report an RMS error of $112 \mathrm{~m}$, and a Mean Absolute Error of $52 \mathrm{~m}$ for the grid. Larger errors occur locally and are usually associated with very steep topography (e.g. around Peter I Island, and parts of the upper slope). Whereas these data skew the RMS and MAE towards higher values, in truth over half the data have a local error $<10 \mathrm{~m}$, and $\sim 70 \%$ of the dataset $<30 \mathrm{~m}$. These results suggest that the final interpolation adheres well to the input measurements. 
Overall, this compilation is a major step in data representation for the Bellingshausen Sea compared to the BEDMAP and recent ALBMAP compilations (Fig. 1b), and reveals more detail than found within new continent-wide datasets (Timmerman et al., 2010). Digital versions of this grid are available for download at: http://doi.pangaea.de/10.1594/ PANGAEA.746255 in netcdf and ArcGIS- compatible ascii raster formats (also included as a Supplement to the paper).

\section{Discussion}

Our new bathymetry resolves major topographic features of the Bellingshausen Sea shelf in detail for the first time. At 1$\mathrm{km}$ resolution, the grid is of a much higher resolution than current coupled ice-ocean or ice-sheet models require because such simulations are computationally intensive and require a significant amount of running time, especially where working in large regional domains. However, even when resampled to lower resolutions, the differences in our grid compared to alternative counterparts are such that the new bathymetry should be useful immediately. Furthermore we anticipate future improvements to model "ability" (i.e. resolution and processing capability; Holland et al., 2010) which will allow for the use of more detailed boundary conditions with time.

A main observation is the continuity of cross-shelf troughs from the shelf edge to the modern ice-shelf fronts. Several studies have suggested that warm CDW must reach the iceshelf fronts in the SBS to explain high rates of basal melting observed there (Talbot, 1988; Jenkins and Jacobs, 2008; Holland et al., 2010). The new grid demonstrates that continuous connections exist between the shelf edge where CDW originates, and each of the southern George VI and Wilkins ice shelves, and Eltanin Bay ice front, via Belgica and Latady Troughs. Ferrigno glacier in particular, which has exhibited dynamic thinning and which may be an analogue for fastchanging glaciers such as Pine Island Glacier, has a continuous bathymetric link to the shelf edge along which the minimum depth is only slightly shallower than $600 \mathrm{~m}$, except across a ridge near to its modern grounding line (at $400 \mathrm{~m}$; Fig. 4c). The current surface elevation change of Ferrigno glacier is measured at $\sim-6 \mathrm{~m} \mathrm{yr}^{-1}$ at the grounding line, which makes the ice stream one of the most dynamic on the Pacific margin of West Antarctica outside of the Amundsen Sea sector (Pritchard et al., 2009).

Warming as a result of CDW intrusion onto the inner shelf has been cited repeatedly as an explanation for the recent thinning and rereat of some West Antarctic glaciers, and this appears to be the most likely cause for Ferrigno glacier's current changes (Rignot and Jacobs, 2002). However, the apparent ridge at the grounding line of the glacier would pose a clear obstacle to any deep-water ocean influence on the ice margin, if the sill were real. Thus, the simplest interpretation at present is that the sill imaged in our grid is an artefact of existing topographic datasets and warm CDW does actually find access to the grounding line via the glacial cross-shelf trough. An embayment at the latitude and with the shape of Eltanin Bay would typically host an ice shelf, so the absence of an ice-shelf or floating ice tongue today supports the presence of a warm-water influence right up to the modern coastline. Further survey of the glacier's grounding line is warranted however, to substantiate the presence or absence of a sill, and to establish possible mechanisms behind recent ice-sheet thinning in the SBS.

In contrast, oceanographic models of GVIIS indicate that virtually all of its current melting variability is driven by ocean processes at the southern end of the sub-ice cavity, in Ronne Entrance (Holland et al., 2010). Our grid shows both the Latady Trough and Belgica Trough connect to the southern limb of GVIIS through bathymetric deeps of 800$1000 \mathrm{~m}$. Likewise, the base of the Wilkins Ice Shelf is connected to the shelf edge via the 600-1000 m deep Latady Trough. Although surface water might be a significant factor in melting these "throughflow" ice shelves (Holland et al., 2010), interaction with warmer deep water masses is likely to play an important role in promoting high basal melt rates and ice-shelf changes in the SE Bellingshausen Sea.

The improved morphological characterisation of Belgica Trough also reveals that the outermost shelf slopes seaward and the trough gradient is relatively flat on the mid to outer shelf (Fig. 4c). In most other large palaeo-ice stream troughs in Antarctica, the outer shelf exhibits a distinct reverse slope towards marked and deep (up to $1500 \mathrm{~m}$ ) inner shelf basins near to the coastline (e.g. Pine Island Trough; Graham et al., 2010). Theoretical studies have suggested that reverse gradient ice-sheet beds are a causal factor in ice-stream instability and fast grounding line retreat (Vaughan and Arthern, 2007; Katz and Worster, 2010). However, a recent chronology presented for the retreat of palaeo-ice in Belgica Trough highlighted an unusually slow and continuous deglaciation for the WAIS in the SBS (calculating mean retreat rates of $7-55 \mathrm{~m} \mathrm{yr}^{-1}$ ) (Hillenbrand et al., 2010). We hypothesise that the unusual shape of the outer shelf, together with a shallower trough profile, may have been influential for the style of ice-sheet recession in the Belgica Trough drainage catchment. Moreover, the mouth of Belgica Trough forms the deepest part of the shelf edge around West Antarctica which may be a reason why the WAIS apparently began its retreat early across this part of the continental margin (Hillenbrand et al., 2010).

A further feature which defines Belgica Trough's morphology is its second-order trough (Fig. 4). The feature's location, nested within the larger Belgica Trough on the outer shelf (Figs. 4a, S2), implies a multi-episodic formation for both the main and subordinate troughs. It was previously speculated to have formed by meltwater outbursts during the last deglaciation (Hillenbrand et al., 2009). Imaged here in full for the first time, we propose an alternative genesis for the feature: the trough forming as a result of focused glacial 


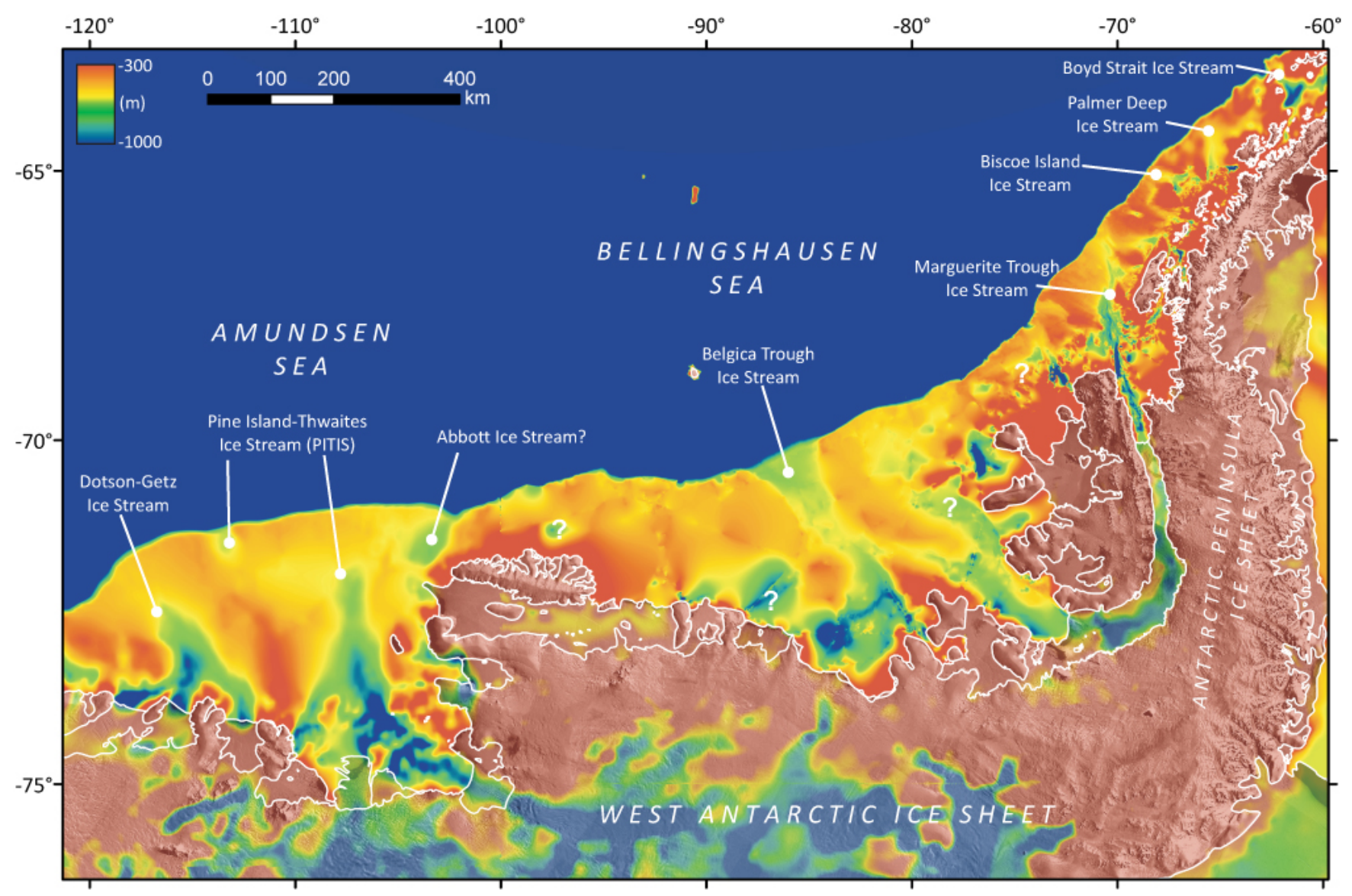

Fig. 5. Compilation of bathymetric charts for the West Antarctic Pacific margin (this study; Rebesco et al., 1998; Nitsche et al., 2007; Bolmer, 2008; Le Brocq et al., 2010), illustrating cross-shelf morphologies which were the principle drainage pathways for numerous palaeoice streams (labelled). Ice stream pathways are identified based on interpretations of Anderson et al. (2002), Heroy and Anderson (2005), Evans et al. (2006), Ó Cofaigh et al. (2005a, b), Domack et al. (2006), Larter et al. (2009) and Graham et al. (2010). 4 areas still requiring investigation are highlighted with a question mark. Mercator WGS84 projection.

erosion along a small zone of enhanced ice flow within a broader fast-flowing ice stream. An analogue for such flow variability already exists in the modern, in cross-stream velocity variations measured on the Carlson-Talutis ice stream (e.g. Vaughan et al., 2008). As such, the second-order trough may pose an interesting site for further study with possible relevance to the flow behaviour of Antarctic ice streams operating today.

In addition, the bathymetry grid offers, for the first time, a sharp definition of the continental margin that was absent in previous compilations (e.g. Figs. 1b, 3). The morphology of the margin and slope is highly significant for modelling along-slope currents and for establishing the precise locations of CDW intrusion onto the shelf. Warm deep water may preferentially move onto the continental shelf via shelf break curvatures and depressions (Dinniman et al., 2004; Walker et al., 2007) so an accurate delineation of the shelf edge can be considered a basic requirement of successful ocean models. Similarly, ice-sheet reconstructions also require a well- defined shelf break to establish the limit of former grounded ice, and the correct shape of the ice-margin has implications for ice-sheet models because changes in ice margin geometry will alter the strain distribution in simulated ice-sheets.

Finally, the new depiction of sea-floor landscape reveals information about the pathways of former ice streams in the SBS. The new grid resolves at least two separate troughs that accommodated fast-flowing ice streams in the past. While Belgica Trough is already well-known as a former ice-stream route (Ó Cofaigh et al., 2005b), Latady Trough is identified here, for the first time, as a probable palaeo-ice stream pathway. Limited bedform data already show fast grounded flow in the upstream portion of this route (Ó Cofaigh et al., 2005b), and unpublished multibeam data reveal streamlined lineations at the sea floor which suggest northerly grounded ice flow west of Latady Island (British Antarctic Survey, unpublished data: included in the compilation). These data imply that the trough was an important outlet for ice draining Alexander Island during glacial periods. Resolving the 
accurate configuration and form of these, and other, major ice streams is crucial for modelling change in the ice sheets through time, as reconstructions of the ancient Antarctic ice sheets validate the use of models for future simulations of change. Thus, the new grid should become a valuable resource for modellers reconstructing palaeo-ice activity in the Bellingshausen Sea and for future expeditions targeting the main channels of ice flow in the past ice sheets.

On a regional scale, our grid adds to a number of others which depict the gross morphology of the West Antarctic Pacific margin, and show it to be dominated by cross-shelf troughs that were carved by, and repeatedly channelled, arteries of ice flow (palaeo-ice streams) to the fringes of the continental shelf during periods of more extensive glaciation (Fig. 5). A compilation of these bathymetric charts illustrates at least 8 known palaeo-ice stream systems between 120 $60^{\circ} \mathrm{W}$ which were active at the Last Glacial Maximum, and highlights an additional 4 areas in the SBS region where the history of ice flow is almost entirely unknown (Fig. 5). These latter regions require further marine geological investigation especially since the few data that do exist indicate the potential for additional ice-formed troughs. In the meantime, the newly-improved regional bathymetry can be used immediately to test the reproducibility of ice stream locations and to constrain the patterns of long-term deglaciation within icesheet models of the palaeo-WAIS and Antarctic Peninusla Ice Sheet. Future improvements to the grid can only help in constraining these models further, and may be achieved through additional grid processing to remove trackline artefacts, integration of novel bathymetric datasets (e.g. Padman et al., 2010), and targeted sonar mapping in areas not yet visited by research vessels.

\section{Summary}

We produced the most detailed bathymetric grid to-date for the hitherto poorly mapped southern Bellingshausen Sea in West Antarctica. Our dataset shows that glacial troughs carved out by the WAIS and Antarctic Peninsula Ice Sheet during repeated glaciations of the continental shelf are now probably instrumental in delivering warm CDW to the ice margin, which has been a factor in the recent rapid demise of both grounded and floating ice in the Bellingshausen Sea. Use of our grid in future ice and ocean models is strongly encouraged, to help determine WAIS stability and forecast future loss from the ice sheets which translates directly into global sea-level. We also identify the wider application of the new bathymetry for mapping benthic biodiversity and regional biological trends (e.g. the Census of Antarctic Marine Life (CAML) community), habitat mapping across different sea-floor terrains, structural geological and tectonic reconstructions of the West Antarctic continent which utilise present-day sea-floor topography (e.g. Eagles et al., 2009), as well as a starting point for reconstructions of Antarctic palaeo-topography.

\section{Supplementary material related to this article is available online at: http://www.the-cryosphere.net/5/95/2011/ tc-5-95-2011-supplement.zip.}

Acknowledgements. We thank the captains, officers and crews of the RRS James Clark Ross and R/V Polarstern, and shipboard parties of numerous other cruises, for collecting data. Deb Shoosmith is thanked for providing JR165 bathymetry. Hans Werner Schenke and Karsten Gohl (both affiliated to Alfred Wegener Institute for Polar and Marine Research) supplied valuable data for the final compilation. Stewart Jamieson is thanked for his encouragement and constructive criticism of our work, and the three reviewers are gratefully acknowledged for helping improve the manuscript. This work forms a contribution to the Ice Sheets component of the British Antarctic Survey "Polar Science for Planet Earth" Programme. It was funded by The Natural Environment Research Council (AGCG and RDL). F. Nitsche was supported by NSF grant ANT-0838735.

Edited by: C. O’Cofaigh

\section{References}

Anderson, J. B., Shipp, S. S., Lowe, A. L., Wellner, J. S., and Mosola, A. B.: The Antarctic Ice Sheet during the Last Glacial Maximum and its subsequent retreat history - a review, Quaternary Sci. Rev., 21, 49-70, 2002.

Bathmann, U.: The expedition ANTARKTIS XVIII/5b of the research vessel "Polarstern" in 2001, Berichte zur Polar- und Meeresforschung, 407, 98 pp., 2002.

Beaman, R. J., O'Brien, P. E., Post, A. L., and De Santis, L.: A new high-resolution bathymetry model for the Terre Adelie and George V continental margin, East Antarctica, Antarct. Sci., 23, 95-103, doi:10.1017/S095410201000074X, 2011.

Bingham, R. G., King, E. C., Larter, R. D., Pritchard, H. D., Smith, A. M., and Vaughan, D. G.: Ferrigno Ice Stream, West Antarctica: new boundary conditions for a catchment losing ice rapidly to dynamic thinning, Geophys. Res. Abstr., Vol. 12, EGU20104657, 2010.

Bolmer, S. T.: A note on the development of the bathymetry of the continental margin west of the Antarctic Peninsula from $65^{\circ}$ to $71^{\circ} \mathrm{S}$ and $65^{\circ}$ to $78^{\circ} \mathrm{W}$, Deep-Sea Res. Pt. II., 55, 271-276, 2008.

Caress, D. W. and Chayes, D. N.: MB-system: Mapping the Seafloor, available at: http://www.ldeo.columbia.edu/res/pi/ MB-System/, access: 28 September 2010, 2006.

Cook, A. J. and Vaughan, D. G.: Overview of areal changes of the ice shelves on the Antarctic Peninsula over the past 50 years, The Cryosphere, 4, 77-98, doi:10.5194/tc-4-77-2010, 2010.

Dinniman, M. S. and Klinck, J. M.: A model study of circulation and cross-shelf exchange on the west Antarctic Peninsula continental shelf, Deep-Sea Res. Pt. II, 51, 2003-2022, 2004.

Domack, E. W., Amblas, D., Gilbert, R., Brachfeld, S., Camerlenghi, A., Rebesco, M., Canals, M., and Urgeles, R.: Subglacial 
morphology and glacial evolution of the Palmer deep outlet system, Antarctic Peninsula, Geomorphology, 75, 125-142, 2006.

Dowdeswell, J. A., Ó Cofaigh, C., Noormets, R., Larter, R. D., Hillenbrand, C.-D., Benetti, S., Evans, J., and Pudsey, C. J.: A major trough-mouth fan on the continental margin of the Bellingshausen Sea, West Antarctica: the Belgica Fan, Mar. Geol., 252, 129-140, 2008.

Dowdeswell, J. A., Evans, J., and Ó Cofaigh, C.: Submarine landforms and shallow acoustic stratigraphy of a $400 \mathrm{~km}$-long fjord-shelf-slope transect, Kangerlussuaq margin, East Greenland, Quaternary Sci. Rev., 29, 3359-3369, doi:10.1016/j.quascirev.2010.06.006, 2010.

Eagles, G., Larter, R. D., Gohl K., and Vaughan, A. P. M.: West Antarctic Rift System in the Antarctic Peninsula, Geophys. Res. Lett., 36, L21305, doi:10.1029/2009GL040721, 2009.

Evans, J., Dowdeswell, J. A., Ó Cofaigh, C., Benham, T. J., and Anderson, J. B.: Extent and dynamics of the West Antarctic Ice Sheet on the outer continental shelf of Pine Island Bay during the last glaciation, Mar. Geol., 230, 53-72, 2006.

Fretwell, P. T., Tate, A. J., Deen, T. J., and Belcher, M.: Compilation of a new bathymetric dataset of South Georgia, Antarct. Sci., 21, 171-174, 2009.

Gohl, K.: The Expedition ANTARKTIS-XXIII/4 of the Research Vessel "Polarstern" in 2006, Berichte zur Polar- und Meeresforschung, 557, 166 pp., 2006.

Graham, A. G. C., Larter, R. D., Gohl, K., Dowdeswell, J. A., Hillenbrand, C.-D., Smith, J. A., Evans, J., Kuhn, G., and Deen, T. J.: Flow and retreat of the Late Quaternary Pine IslandThwaites palaeo-ice stream, West Antarctica, J. Geophys. Res., 115, F03025, doi:10.1029/2009JF001482, 2010.

Heroy, D. C. and Anderson, J. B.: Ice-sheet extent of the Antarctic Peninsula region during the Last Glacial Maximum (LGM) - Insights from glacial geomorphology, Geol. Soc. Am. Bull., 117, 1497-1512, 2005.

Hillenbrand, C.-D., Ehrmann, W., Larter, R. D., Benetti, S., Dowdeswell, J. A., Ó Cofaigh, C., Graham, A. G. C., and Grobe, H.: Clay mineral provenance of sediments in the southern Bellingshausen Sea reveals drainage changes of the West Antarctic Ice Sheet during the Late Quaternary, Mar. Geol., 265, 1-18, 2009.

Hillenbrand, C.-D., Larter R. D., Dowdeswell, J. A., Ehrmann, W., Ó Cofaigh, C., Benetti, S., Graham, A. G. C., and Grobe, H.: The sedimentary legacy of a palaeo-ice stream on the shelf of the southern Bellingshausen Sea: Clues to West Antarctic glacial history during the Late Quaternary, Quaternary Sci. Rev., 29, 2741-2763, doi:10.1016/j.quascirev.2010.06.028, 2010.

Holland, P. R., Jenkins, A., and Holland, D. M.: Ice and ocean processes in the Bellingshausen Sea, Antarctica, J. Geophys. Res., 115, C05020, doi:10.1029/2008JC005219, 2010.

Hollister, C. D. and Craddock, C.: Deep Sea Drilling Project, Leg 35: Bellingshausen Sea, Antarct. J. US, 9, 1-19, 1974.

Jacobs, S. S. and Comiso, J. C.: Climate variability in the Amundsen and Bellingshausen seas, J. Climate, 10, 697-709, 1997.

Jakobsson, M., Macnab, R., Mayer, L., Anderson, R., Edwards, M., Hatzky, J., Schenke, H. W., and Johnson, P.: An improved bathymetric portrayal of the Arctic Ocean: Implications for ocean modelling and geological, geophysical and oceanographic analyses, Geophys. Res. Lett., 35, L07602, doi:10.1029/2008GL033520, 2008.
Jenkins, A. and Jacobs, S. S.: Circulation and melting beneath George VI Ice Shelf, Antarctica, J. Geophys. Res., 113, C04013, doi:10.1029/2007JC004449, 2008.

Katz, R. F. and Worster, G.: Stability of ice-sheet grounding lines, P. R. Soc. A, 466, 1597-1620, doi:10.1098/rspa.2009.0434, 2010.

Kellogg, D. E. and Kellogg, T. B.: Microfossil distributions in modern Amundsen Sea sediments, Mar. Micropaleontol., 12, 203222, 1987.

Larter, R. D., Gohl, K., Hillenbrand, C. D., Kuhn, G., Deen, T. J., Dietrich, R., Eagles, G., Johnson, J. S., Livermore, R. A., Nitsche, F. O., Pudsey, C. J., Schenke, H. W., Smith, J. A., Udintsev, G. B., and Uenzelmann-Neben, G.: West Antarctic Ice Sheet change since the last glacial period, Eos, 88, 189-190, 2007.

Larter, R. D., Graham, A. G. C., Gohl, K., Kuhn, G., Hillenbrand, C.-D., Smith, J. A., Deen, T. J., Livermore, R. A., and Schenke, H.-W.: Subglacial bedforms reveal complex basal regime in a zone of paleo-ice stream convergence, Amundsen Sea embayment, West Antarctica, Geology, 37, 411-414, 2009.

Le Brocq, A. M., Payne, A. J., and Vieli, A.: An improved Antarctic dataset for high resolution numerical ice sheet models (ALBMAP v1), Earth Syst. Sci. Data Discuss., 3, 195-230, doi:10.5194/essdd-3-195-2010, 2010.

Lythe, M. B., Vaughan, D. G., and the BEDMAP consortium: BEDMAP: A new ice thickness and subglacial topographic model of Antarctica, J. Geophys. Res., 106, 11335-11351, 2001.

Macnab, R.: Houston, We Have a Problem: Satellite Altimetry Skews Ocean Depths, Eos Trans. AGU, 90, 312, doi:10.1029/2009EO360003, 2009.

Maslanyj, M. P.: Seismic bedrock depth measurements and the origin of George VI Sound, Antarctic Peninsula, Brit. Antarct. Surv. B., 75, 51-65, 1987.

Miller, H. and Grobe, H.: The expedition ANTARKTIS-XI/3 of RV "Polarstern" in 1994, Berichte zur Polar- und Meeresforschung, 188, 115 pp., 1994.

Nitsche, F. O., Cunningham, A. P., Larter, R. D., and Gohl, K.: Geometry and development of glacial continental margin depositional systems in the Bellingshausen Sea, Mar. Geol., 162, 277 302, 2000.

Nitsche, F. O., Jacobs, S. S., Larter, R. D., and Gohl, K.: Bathymetry of the Amundsen Sea continental shelf: Implications for, geology, oceanography and glaciology, Geochem. Geophy. Geosy., 8, Q10009, doi:10.1029/2007GC001694, 2007.

Noormets, R., Dowdeswell, J. A., Larter, R. D., Ó Cofaigh, C., and Evans, J.: Morphology of the upper continental slope in the Bellingshausen and Amundsen seas - implications for sedimentary processes at the shelf edge of West Antarctica, Mar. Geol., 258, 100-114, 2009.

Ó Cofaigh, C., Pudsey, C. J., Dowdeswell, J. A., and Morris, P: Evolution of subglacial bedforms along a paleo-ice stream, Antarctic Peninsula continental shelf, Geophys. Res. Lett., 29, 1199, doi:10.1029/2001GL014488, 2002.

Ó Cofaigh, C., Dowdeswell, J. A., Allen, C. S., Hiemstra, J., Pudsey, C. J., Evans, J., and Evans, D. J. A.: Flow dynamics and till genesis associated with a marine-based Antarctic palaeo-ice stream, Quaternary Sci. Rev., 24, 709-740, 2005 a.

Ó Cofaigh, C., Larter, R. D., Dowdeswell, J. A., Hillenbrand, C.-D., Pudsey, C. J., Evans, J., and Morris, P.: Flow of the West Antarctic Ice Sheet on the continental margin of the Bellingshausern Sea at the last glacial maximum, J. Geophys. Res., 110, B11103, 
doi:10.1029/2005JB003619, 2005b.

Overpeck, J. T. and Weiss, J. L.: Projections of future sea level becoming more dire, P. Natl. Acad. Sci., 106, 21461-21462, 2009.

Padman, L., Costa, D. P., Bolmer, S. T., Goebel, M. E., Huckstadt, L. A., Jenkins, A., McDonald, B. I., and Shoosmith, D. R.: Seals map bathymetry of the Antarctic continental shelf, Geophys. Res. Lett., 37, L21601, doi:10.1029/2010GL044921, 2010.

Pritchard, H. D. and Bingham, R. G.: Exploration glaciology: radar and Antarctic ice, Physics Education, 42, 442-456, 2007.

Pritchard, H. D., Arthern, R. J., Vaughan, D. G., and Edwards, L. A.: Extensive dynamic thinning on the margins of the Greenland and Antarctic ice sheets, Nature, 461, 971-975, doi:10.1038/nature08471, 2009.

Rebesco, M., Camerlenghi, A., and Zanolla, C.: Bathymetry and Morphogenesis of the Continental Margin West of the Antarctic Peninsula, Terra Antarctica, 5, 715-725, 1998.

Rignot, E. and Jacobs, S. S.: Rapid bottom melting widespread near Antarctic Ice Sheet grounding lines, Science, 296, 2020-2023, 2002.

Sandwell, D. T., Smith, W. H. F., Gille, S., Jayne, S., Soofi, K., and Coakley, B.: Bathymetry from Space: White paper in support of a high-resolution, ocean altimeter mission, 5 April 2001, available at: http://topex.ucsd.edu/marine_grav/white_paper.pdf, access: 29 September 2010, 2001.

Scheuer, C., Gohl, K., Larter, R. D., Rebesco, M., and Udintsev, G. B.: Variability in Cenozoic sedimentation along the continental rise of the Bellingshausen Sea, West Antarctica, Mar. Geol., 227, 279-298, doi:10.1016/j.margeo.2005.12.007, 2006.

Sibson, R.: A Brief Description of Natural Neighbor Interpolation, in: Interpolating Multivariate Data, New York: John Wiley \& Sons, 21-36, 1981.

Smith, W. H. F. and Sandwell, D. T.: Bathymetric prediction from dense satellite altimetry and sparse shipboard bathymetry, J. Geophys. Res., 99, 21803-21824, 1994.
Smith, W. H. F. and Sandwell, D. T.: Global seafloor topography from satellite altimetry and ship depth soundings, Science, 277, 1957-1962, 1997.

Talbot, M. H.: Oceanic environment of George VI Ice Shelf, Antarctic Peninsula, Ann. Glaciol., 11, 161-164, 1988.

Thoma, M., Jenkins, A., Holland, D., and Jacobs, S. S.: Modelling Circumpolar Deep Water intrusions on the Amundsen Sea continental shelf, Antarctica, Geophys. Res. Lett., 35, L18602, doi:10.1029/2008GL034939, 2008.

Timmermann, R., Le Brocq, A., Deen, T., Domack, E., Dutrieux, P., Galton-Fenzi, B., Hellmer, H., Humbert, A., Jansen, D., Jenkins, A., Lambrecht, A., Makinson, K., Niederjasper, F., Nitsche, F., Nøst, O. A., Smedsrud, L. H., and Smith, W. H. F.: A consistent dataset of Antarctic ice sheet topography, cavity geometry, and global bathymetry, Earth Syst. Sci. Data Discuss., 3, 231-257, doi:10.5194/essdd-3-231-2010, 2010.

Vaughan, D. G. and Arthern, R.: Why is it hard to predict the future of ice sheets?, Science, 315, 1503-1504, doi:10.1126/science.1141111, 2007.

Vaughan, D. G., Corr, H. F. J., Smith, A. M., Pritchard, H. D., and Shepherd, A.: Flow-switching and water piracy between Rutford Ice Stream and Carlson Inlet, West Antarctica, J. Glaciol., 54, 41-49, 2008

Walker, D. P., Brandon, M. A., Jenkins, A., Allen, J. T., Dowdeswell, J. A., and Evans, J.: Oceanic heat transport onto the Amundsen Sea shelf through a submarine glacial trough, Geophys. Res. Lett., 34, L02602, doi:10.1029/2006GL028154, 2007.

Wellner, J. S., Lowe, A. L., Shipp, S. S., and Anderson, J. B.: Distribution of glacial geomorphic features on the Antarctic continental shelf and correlation with substrate: implications for ice behaviour, J. Glaciol., 47, 397-411, 2001. 